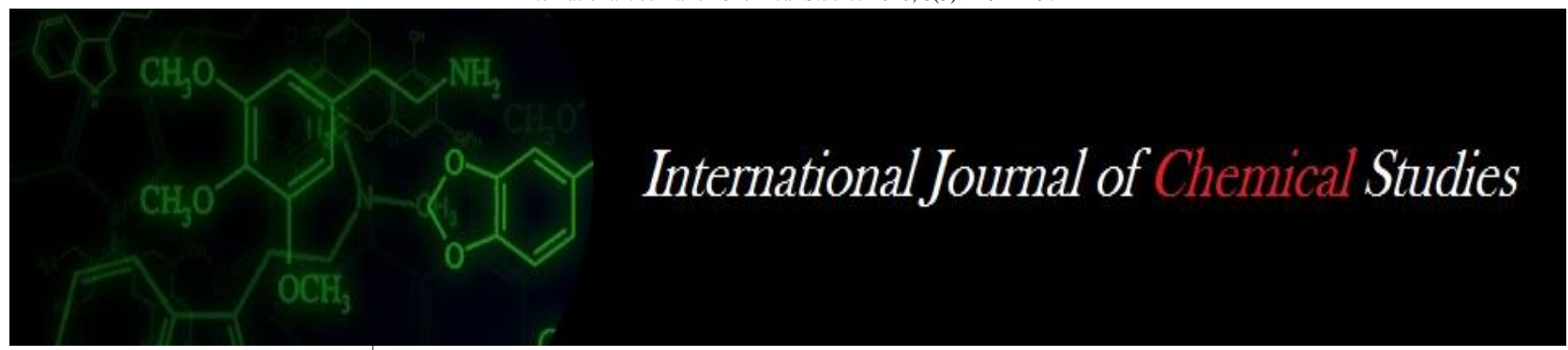

P-ISSN: 2349-8528

E-ISSN: 2321-4902

www.chemijournal.com

IJCS 2020; 8(5): 2191-2197

(C) 2020 IJCS

Received: 16-07-2020

Accepted: 20-08-2020

Deveshwar Prasad Patel Department of Horticulture \& Postharvest Technology, Institute of Agriculture, Visva-Bharati, Sriniketan, West Bengal, India

\section{Prahlad Deb}

Department of Horticulture \&

Postharvest Technology,

Institute of Agriculture,

Visva-Bharati, Sriniketan,

West Bengal, India

Yogesh Kumar Patel

Department of Seed Science and

Technology, Sam

Higginbottom Institute of

Agriculture, Technology and

Sciences, Allahabad,

Uttar Pradesh, India

Corresponding Author: Deveshwar Prasad Patel Department of Horticulture \& Postharvest Technology, Institute of Agriculture, Visva-Bharati, Sriniketan, West Bengal, India

\section{Effect of fruit bagging on yield and quality of tomato (Solanum lycopersicum $\mathbf{L}$.)}

\author{
Deveshwar Prasad Patel, Prahlad Deb and Yogesh Kumar Patel
}

DOI: $\underline{\text { https://doi.org/10.22271/chemi.2020.v8.i5ad.10632 }}$

\begin{abstract}
Tomato crop requires some of the basic practices during cultivation to obtained high yield and quality attributes without affected from adverse biotic and abiotic factors. These attributes can be maintained though several ways, which will have beneficial for the farmers to fetching better economy from the quality produce into the domestic market or by, export. Among the various practices, fruit bagging has emerged as an effective method. Bagging is a physical protection method which not only improves the visual quality of fruit by promoting skin coloration and reducing blemishes but can also change the micro-environment for fruit development, which can have several beneficial effects on internal fruit quality. Seven different type of bagging (Fruit covering materials) were applied in five randomized selected plants from each plot. These seven bagging are News Paper bagging, Butter Paper bagging, Transparent Polythene Bagging, Black polythene bagging, Muslin net (cloth) bagging, jute bagging and No bagging (control). Different treatments have been shown various effects viz: significantly highest fruit yield $(3.136 \mathrm{~kg} / \mathrm{plant})$ has been recorded under butter paper bagging. Lowest fruit yield was recorded under control $(2.250 \mathrm{~kg} / \mathrm{plant})$ closely followed by jute bag bagging $(2.752 \mathrm{~kg} / \mathrm{plant})$. Significantly highest ascorbic acid $\left(27.33 \mathrm{mg} 100^{-1} \mathrm{~g}\right)$ was recorded in butter paper bag while lowest ascorbic acid

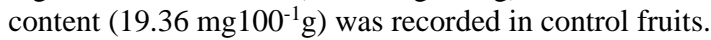

Keywords: Tomato, bagging, lycopene, quality attributes, microenvironment, yield

\section{Introduction}

Tomato (Solanum lycopersicum L.,) is a perennial crop but some of its cultivars are grown as an annual crop in various parts of the world and it belongs to the diverse family Solanaceae, which includes more than 3000 species, occupying a wide variety of habitats ${ }^{[1]}$. The tomato is considered as "Poor man's Orange" in India while "Love of Apple" in England. A native of Peru-Ecuador-Bolivia area of the Andes (South America) with basic chromosome number $2 n=24$, is one of the most popular protective foods because of its high nutritive value, and widely grown vegetables in the world next to potato.Tomato is a warm season vegetable crop requires a long season optimum temperature is 21 to $24^{\circ} \mathrm{C}$. Temperature has been significant influence on growth and development of tomato fruits ${ }^{[2]}$. Temperature and light intensity affected the fruit set, pigmentation and nutritive value. It is a rich source of vitamin $\mathrm{A}$ and $\mathrm{C}$, and also contains minerals like iron, phosphorus ${ }^{[40]}$. Furthermore, tomato is the richest source of nutrients, dietary fibers antioxidant like lycopene and $\beta$-carotene, the compounds that protect cells from cancer ${ }^{[40]}$. Several epidemiological studies have underlined the beneficial effect of tomato consumption in the prevention of chronic diseases such as cancer and cardiovascular disease ${ }^{[3]}$. This effect has been attributed mainly to the antioxidant activity of tomato phyto-chemicals, in particular lycopene, a very efficient radical quencher capable to neutralize reactive oxygen and thus avoid cell injury; however several other mechanisms of the healthy action of carotenoids have been suggested ${ }^{[3]}$. Tomato plant is highly affected by serious insects (fruit borer) and diseases (late blight) which causes deteriorate fruit quality and reduced yield. The affected fruits gain poor price in the market and such fruits are also rejected for processing. It causes serious economic loss to mango growers ${ }^{[35]}$. The abiotic factors viz. temperature and humidity play critical role in fruit growth and development. Temperature is the most important environmental factor that affects quality, very low or very high temperature may injure sensitive crops. High temperature $\left(35^{0} \mathrm{C}\right)$ specially inhibits accumulation of lycopene due to stimulation of conversion of lycopene into $\beta$-carotene ${ }^{[5]}$. Tomato is a very good source of income to small and marginal farmers, and provides nutrients to the consumers. 
Quality of the produce is the final manifestation of interrelation between the commodity and its environment. Fresh tomato quality is determined by appearance, flavor, colour, firmness; the latter two qualities attributes being major factors in consumer preference of tomatoes ${ }^{[6]}$. Fruit color is the basic point of attraction for the consumers. Attractive colour improves the physical appearance of the fruit, which helps to get better price in the domestic or export market ${ }^{[7,41]}$. Preharvest fruit bagging has emerged as a novel technology in practice, which is simple, grower friendly, safe and beneficial for production of quality fruits ${ }^{[8]}$. Bagging is a physical protection method which not only improves the visual quality of fruit by promoting skin colouration and reducing blemishes, but can also change the micro-environment for fruit development, which can have several beneficial effects on internal fruit quality ${ }^{[35,42]}$. Pre-harvest bagging of fruit is practiced in Japan, Australia, and China during peach, apple, pear, grape, and loquat cultivation in order to optimize fruit quality by reducing physiological and pathological disorders and to improve fruit colouration to increase market value leading to an improved appearance $[13,19]$. Some countries such as Mexico, Chile, Argentina do not import apples unless they are bagged ${ }^{[35]}$. There have been contradictory reports on the effects of pre-harvest fruit bagging on fruit size, maturity, skin colour, flesh mineral content, and fruit quality, all of which may be due to differences in the type of bag used, the stage of fruit development when bagged, the duration of exposure to natural light following bag removal and/or fruitand cultivar-specific responses ${ }^{[12,35,42]}$. Pre-harvest bagging with different types of bag has given significant result on the physical quality of fruits. In a field experiment was conducted by at Ratnagiri, Maharashtra on influence of bagging of fruits at marble Stage on quality of mango cv. Alphonso ${ }^{[8]}$. Bagging of tomato fruit clusters with TNT or organza fabric may be an excellent option to reduce damage by insect borers and diseases for a significant economic gain ${ }^{[10]}$. Bagging can prevent damage by insects and reduce pesticide use, without interfering with fruit formation and color development ${ }^{[10]}$. Thus, these all yield and qualitative attributes was observed by pre-harvest fruit bagging on tomato at marble stage of fruits in experimental field.

\section{Materials and Methods}

The present investigation was conducted on during winter season of 2016-17 at the Horticultural Farm of Palli Siksha Bhavana (Institute of Agriculture), Visva-Bharati, Sriniketan. The Farm is situated at $23^{\circ} 40^{\prime} \mathrm{N}$ latitude and $87^{\circ} 40^{\prime} 3$ '” longitude, and at an altitude of 40 meter above the mean sea level under sub-humid, sub-tropical and lateritic belt of WestBengal. The experiment was carried out in a Randomized Block Design with 4 replications to assess the performance of different bagging materials. Seven different type of bagging (Fruit covering materials) were applied in five randomized selected plants from each plot. These seven bagging are News Paper bagging $\left(\mathrm{T}_{1}\right)$, Butter Paper bagging $\left(\mathrm{T}_{2}\right)$, Transparent Polythene Bagging $\left(\mathrm{T}_{3}\right)$, Black polythene bagging $\left(\mathrm{T}_{4}\right)$, Muslin net (cloth) bagging $\left(\mathrm{T}_{5}\right)$, jute bagging $\left(\mathrm{T}_{6}\right)$ and No bagging or control $\left(\mathrm{T}_{7}\right)$. The crop was raised in check basin system. The seeds of tomato were sown in nursery beds in row to row and line to line on $7^{\text {th }}$ November, 2016. Seedlings of tomato were transplanted on $1^{\text {st }}$ December, 2016 at a spacing $60 \mathrm{~cm}$ (plant to plant) and $45 \mathrm{~cm}$ (row to row). Five randomly selected plants of each plots and replications were tagged for data collection. Fruit bagging were done with different bagging materials at marble stage during $1^{\text {st }}$ week of February, 2017.
Fruits have been harvested after maturity and subjected to physio-chemical observations as well as storage study. The physical and chemical composition was estimated by the following procedures:

Yield per plant (kg): The weight of every fruits from each of the five randomized selected plants was recorded with the help of an electrical balance and got the average value after calculated.

Yield per hectare (q): The yield per hectare was estimated from yield per plant.

Fruit weight (g): The weight of an every fruits was recorded with the help of an electrical balance.

Fruit polar diameter (mm): The polar diameter of the fruit was measured at the both top and bottom central end portion of fruits by the slide caliper.

Fruit equatorial diameter (mm): The equatorial diameter of the fruit was measured at the both side of middle portion of fruits with help of the slide caliper.

Fruit volume (ml): Volume of fruit was measured by beaker into filled water, with the dipping of every fruit and calculated.

Post harvest storage (days): It was measured by storing days of fresh fruit in the glass trays in room temperature at $26^{\circ} \mathrm{c}$ and calculated the spoilage days of the fruits.

Total soluble solid ( ${ }^{\circ}$ Brix): Total soluble solid contain of the fruit juice was measured with the help of an ERMA hand refractometer (o - $32^{\circ}$ Brix) corrected at $20^{\circ} \mathrm{C}$. The refractometer was adjusted at $0 \%$ level with the help of distilled water and clean with cotton and dried. The data thus obtained were adjusted for temperature correction from standard correction table.

Reducing sugar and total sugar (\%): Total and reducing sugar contents of the fruit extracted juice was determinate by titrating against Fehling solution $\mathrm{A}$ and $\mathrm{B}$ reagents using methyl blue as an indicator ${ }^{[21]}$. The reducing sugar content was calculated by the following formula:

Reducing sugar (\%) in the juice (i.e. $\mathrm{g}$ of glucose/100g of juice $)=20 / x$

Where, $\mathrm{x}=$ burette reading.

Ascorbic acid (\%): Ascorbic acid was analysis with 3\% metaphosphoric acid by titrating against the dye solution i.e. $V_{2}{ }^{[21]}$. The ascorbic acid calculated by the following formula:

Amount of ascorbic acid mg/100g sample.

$\begin{aligned} & \begin{array}{c}0.5 \mathrm{mg} \quad \mathrm{V}_{2} \\ \ldots \ldots \ldots \ldots \ldots \ldots \ldots \ldots \ldots \ldots \ldots \ldots \ldots\end{array} \times 100 \\ \mathrm{~V}_{1} \mathrm{ml} \quad 5 \mathrm{ml} \quad \text { weight of sample. } & \end{aligned}$

Lycopene content (\%): Lycopene content was estimated by spectrophotometric method as per Davies (1976) and expressed as $\mathrm{mg} / 100 \mathrm{~g}$ of fruit pulp. The osmotic density of the solution recorded by spectrophotometer at $503 \mathrm{~nm}$ visual wave length taking petroleum ether: acetone in 97:3 as reference. The lycopene content had calculated by the following formula: 
$3.1206 \times$ OD value $x$ Final value $\mathrm{x}$ Dilution $\mathrm{x} 100$

Lycopene $(\mathrm{mg} / 100 \mathrm{~g})=$

Weight of the sample.

Where, Absorbance $(1$ unit $)=3.1206 \mu \mathrm{g}$ of lycopene $/ \mathrm{ml}$.

Dry weight $(\%)$ : The dry weight of fruit was calculated with the following formula:

$$
\% \text { dry weight of fruit pulp }=\frac{\text { DW }}{-\cdot---} \times 100
$$

Where, FW= Fresh weight of fruit pulp and DW = Dried weight of fruit pulp.

Per cent total weight loss of fruit: Per cent weight loss was calculated by using following formula:

$$
\text { Percent weight loss }(\% \mathrm{WL})=\frac{\text { IW-FW }}{\text { IW }} \text { x } 100
$$

Where, \% WL: Per cent weight loss, IW: Initial fruit weight with crown and FW: Final fruit weight.

\section{Results and Discussion}

The present experiment was carried out to study the "Effect of fruit bagging on yield and quality of tomato (Solanum lycopersicum L.) under sub-humid tropics of West Bengal, at Horticulture Farm, Department of Horticulture and Post Harvest Technology, Palli Siksha Bhavana (Institute of Agriculture), Visva-Bharati, Sriniketan West Bengal during 2016-17.

\section{Visual appearance of the fruit}

In the present experiment the visual appearance on the basis of shape, size, freshness etc. it was noted that unblemished bright red peel and pulp colour fruit was found in butter paper bag whereas un-bagged fruits colour was not more satisfied. Although, both bagged and unbagged fruits have attained maturity more or less same time.

In an experiment also found that the cosmetic quality and appearance of litchi fruits can be improved by bagging fruits ${ }^{[30]}$. It has now been established that fruit bagging is an effective way to promote anthocyanin synthesis and improve fruit coloration in apples ${ }^{[34]}$. So the findings of the present experiment have conformity with the findings of Purbey and Kumar (2015) ${ }^{[7,34]}$.

\section{Fruit weight (g.)}

The result of the present experiment shows that the fruits weight of tomato signifantly effected by fruit bagging (table 1 and figure 1). Significantly maximum fruit weight was obtained in case of butter paper bag $(59.93 \mathrm{~g}$ ) followed by control $(57.57 \mathrm{~g})$ and lowest fruit weight was observed in transparent polythene bagging $(49.46 \mathrm{~g})$.

Increase in fruit size may be due to the development of specific microclimate favourable for fruit development as a result of using bagging materials. Bagging increased fruit weight, size over unbagged control fruits reported by Chonhenchob et al., 2011 and Purbey and Kumar, 2015. Thus the result of the present experiment corroborates the findings of Chonhenchob et al. (2011) and Purbey and Kumar (2015) $[7,23]$.
Fruit polar diameter ( $\mathbf{m m})$ and equatorial diameter $(\mathbf{m m})$ Observations on polar diameter of tomato fruits revealed that bagging of fruits has significant effect on polar diameter which was ranged from 40.30 to $48.79 \mathrm{~mm}$ (table 1 and figure 1). Maximum fruit polar diameter has been obtained in butter paper bag $(48.79 \mathrm{~mm})$ followed by news paper bag $(47.47$ $\mathrm{mm})$ and lowest in control $(40.30 \mathrm{~mm})$.

Significantly highest fruit equatorial diameter was noticed in news paper bagging $(58.07 \mathrm{~mm})$ whereas lowest was observed under control $(45.65 \mathrm{~mm})$. Smilar trend has been found in the experiment done by Chonhenchob et al. (2011) where bagging increased fruit weight, size over unbagged (control) fruits ${ }^{[23]}$. It is because of temperature has been significant influence on growth and development of tomato fruits ${ }^{[11]}$.

\section{Days to first harvest from bagging (day)}

It is clear from the data presented $\mathrm{n}$ the table 1 and figure 2 that, the significantly earliest harvesting is done under polythene bagging (within 21.24 days), whereas the late harvesting was noted in un-bagged or control at 27.08 days.

It is because of inside the bag higher accumulation of $\mathrm{CO}_{2}$ and light through transparency of bagging materials, consequently might increasing transpiration rate and ethylene synthesis and transformation of chloroplasts into chromoplasts and from the degradation of chlorophyll in tomato thereby achieved early maturity of fruit resulting possible to early harvesting by reducing the delay of maturity. Similar result also found by different scientists these are (Fallahi, Colt, Baird, \& Chun, 2001 Debnath \& Mitra, 2007; Leite et al., 2014) ${ }^{[9,10,43,44]}$.

\section{Fruit volume (ml)}

Statistical analysis of observations on fruit volume reveals that fruit bagging with different materials has increased fruit volume (table 1 and figure 1). In the present study fruit volume was found higher under butter paper bag $(71.76 \mathrm{ml})$ which was statistically at par with news paper bagging (71.12 $\mathrm{ml})$ and the lowest fruit volume was noticed in control (51.34 $\mathrm{ml})$.

This higher fruit volume may be attributed to higher respiration rate, biochemical changes and low humidity surrounding the fruit. Similar result of also found by Harach and Wanichkul, $2006^{[43,45]}$.

\section{Average number of fruits}

Different types of bagging influenced the fruit production of tomato plants which is evident from the data of average number of fruits presented in the table number 1 and figure 2 . Significantly maximum numbers of fruits were found under transparent polythene bagging (62.75). Lowest number of fruits has been observed under control (29.50)

Increase in number of fruits may be due to the influence of bagging of existing fruits on flowering and fruit set of the plants.

\section{Yield (kg) per plant}

The result of the present experiment shows the significant variation of yield of tomato plants as effected by fruit bagging (table 1 and figure 2). Significantly highest fruit yield (3.136 $\mathrm{kg} /$ plant) has been recorded under butter paper bagging. Lowest fruit yield was recorded under control $(2.250$ $\mathrm{kg} /$ plant) closely followed by jute bag bagging $(2.752$ $\mathrm{kg} /$ plant). 
This increase in yield was due to the higher number of fruits along with higher fruit weigh which collectively increased fruit yield/plant. Because of bagging decrease light intensity inside the bagging material thus increase humidity and temperature and on the fruit. It also reduces fruit transpiration water loss during growth ${ }^{[12,13,18,23]}$.

Total Soluble Solids (TSS in ${ }^{\mathbf{0}}$ Brix): Statistical analyses of observation on total soluble solids (table 2 and figure 3 ) denote that bagging of tomato fruits by different materials has significant effect on total soluble solids of fruits. In the present experiment maximum TSS was found under news paper bagging $\left(6.18^{\circ}\right.$ Brix $)$ which was at par with jute bagging fruits $\left(5.92^{\circ} \mathrm{Brix}\right)$; closely followed by butter paper bagging $\left(5.89^{\circ}\right.$ Brix $)$. However, significantly minimum TSS has been observed in black polythene bag (4.01).

Increase in TSS is due to increased accumulation of reducing sugars and partial breakdown of pectin and celluloses during ripening. Similar finding of TSS increment by fruit bagging on other fruits was reported by Worrell et al. (1998) ${ }^{[14]}$.

Total sugar (\%): Effect of bagging of different materials on tomato fruits was significant (table 2 and figure 3 ). The observation on total sugar reveals that the treatments varied from 4.01 to $6.18 \%$ with respect to total sugar. Significantly highest total sugar $(6.18 \%)$ was recorded in news paper bag. On contrary lowest total sugar has been recorded under black polythene bag $(4.01 \%)$ which was statistically at par with control (4.12\%).

The variation in total sugar under different bagging treatment may be attributed to the variation of microclimate developed inside various bagging materials. Worrell et al. (1998) reported the increase $\mathrm{n}$ sugar content of fruits when covered with different materials ${ }^{[14]}$.

Reducing sugar (\%): The result of the present experiment shows significant variation in reducing sugar of tomato fruits covered with various bagging materials (table 2 and figure 3 ). The range of reducing sugar varied from 1.08 to $1.90 \%$. Significantly highest reducing sugar was recorded in fruits covered with butter paper bags $(1.90 \%)$ which was lowest in control fruits $(1.08 \%)$. In news paper bagging $1.81 \%$ reducing sugar was recorded which was second highest.

More conversion of large molecule of sugars into simpler form under protected condition i.e. under bagging perhaps the cause of higher reducing sugar in bagged fruits than $\mathrm{n}$ control. Purbey and Kumar (2015) also reported higher reducing sugar in litchi fruits covered by different bagging materials ${ }^{[30]}$.

\section{Acidity (\%)}

It is clear from the data presented in table .2 that the bagging of fruits with various bagging materials has no significant effect on titrable acidity of tomato fruits. However $t$ was ranged from 0.45 to $0.50 \%$. Minimum titrable acidity was observed in fruits covered with news paper bags and maximum titrable acidity has been observed under control. This higher acidity in the uncovered fruits may be due to open condition which offers higher temperature and real time fluctuation of environmental components.

Ascorbic acid content $\left(\mathbf{m g 1 0 0 g}^{-1}\right)$ : The significant result has been observed in the present experiment with respect to the effect of various bagging materials on tomato fruits in its ascorbic acid content (table 2). Significantly highest ascorbic acid $\left(27.33 \mathrm{mg} 100^{-1} \mathrm{~g}\right)$ was recorded in butter paper bag. However, higher ascorbic acid content $\left(26.17 \mathrm{mg} 100^{-1} \mathrm{~g}\right)$ was also recorded under news paper bagging. On the other hand significantly lowest ascorbic acid content $\left(19.36 \mathrm{mg}^{\left.100^{-1} \mathrm{~g}\right)}\right.$ was recorded in control fruits.

The variation in total ascorbic acid under different bagging treatment may be attributed to the variation of microclimate developed inside various bagging materials. Worrell et al. (1998) reported the increase in ascorbic acid content of fruits when covered with different materials ${ }^{[14]}$.

Lycopene content $\left(\mathbf{m g ~} \mathbf{1 0 0 \mathrm { g } ^ { - 1 }}\right)$ : The statistical analysis of the data recorded under lycopene content of tomato fruits reveals that different bagging condition significantly effected the fruit lycopene content (table 2). Lycopene content of tomato fruits varied from 152.33 to $310.26 \mathrm{mg} 100^{-1} \mathrm{~g}$ ). Significantly highest amount of lycopene was found in the fruits covered with butter paper bag $\left(310.26 \mathrm{mg} 100^{-1} \mathrm{~g}\right)$ followed by news paper bag $\left(293.73 \mathrm{mg} 100^{-1} \mathrm{~g}\right)$. However, significantly minimum lycopene content $\left(152.33 \mathrm{mg} 100^{-1} \mathrm{~g}\right)$ was noticed under control treatment.

Higher lycopene content in the covered fruits may be due to the higher conversion of carotenoides lke lycopene by lower light penetration in the covered fruits. However the fruits receved more light under control treatment and transparent polythene bagging has produced less lycopene. The fndngs of Chonhenchob et al. (2011) and Purbey and Kumar (2015) also supports the better colour development of bagged fruits ${ }^{[23,30]}$.

\section{Fruit dry weight (g)}

Perusal of the data on the result of dry weight of fruits has made significant differences under different treatments of fruit bagging noted that, higher dry weight gave from black polythene bag $(5.43 \mathrm{~g})$ and lowest weight in muslin cloth bag (3.70g).

Perhaps bagging decrease light intensity inside the bagging material thus increase humidity and temperature and on the fruit. It also reduces fruit transpiration water loss during growth. Chonhenchob et al. (2011), Amarante et al. (2002a), Joyce et al., (1997) and Hofman (1997) reported the similar findings $[12,13,18,23]$.

Table 1: Effect of fruit bagging on fruit physical parameters and yield of tomato cv. Lakshmi

\begin{tabular}{|c|c|c|c|c|c|c|c|c|}
\hline Treatments & Treatment details & \begin{tabular}{|l} 
Fruit \\
wt (g) \\
\end{tabular} & \begin{tabular}{|c|}
$\begin{array}{c}\text { Polar Diameter } \\
(\mathbf{m m})\end{array}$ \\
\end{tabular} & \begin{tabular}{|c|} 
Equatorial \\
Diameter $(\mathbf{m m})$ \\
\end{tabular} & \begin{tabular}{|c|}
$\begin{array}{c}\text { Volume } \\
(\mathrm{ml})\end{array}$ \\
\end{tabular} & $\begin{array}{c}\text { Average No. of } \\
\text { fruits /plant }\end{array}$ & $\begin{array}{l}\text { Yield }(\mathbf{k g}) \\
\text { per plant }\end{array}$ & $\begin{array}{c}\text { Day to } 1^{\text {st }} \text { harvest } \\
\text { from bagging }\end{array}$ \\
\hline T1 & News Paper Bag & 54.09 & \begin{tabular}{|l|}
47.47 \\
\end{tabular} & 58.07 & 71.12 & 49.00 & 2.813 & 23.15 \\
\hline $\mathrm{T} 2$ & Butter Paper Bag & 59.93 & 48.79 & 56.42 & 71.76 & 54.75 & 3.136 & 23.42 \\
\hline T3 & Transparent Polythene Bag & 49.46 & 42.86 & 48.90 & 58.41 & 62.75 & 2.381 & 21.24 \\
\hline T4 & Black Polythene Bag & 50.74 & 42.92 & 47.31 & 57.09 & 55.00 & 2.457 & 27.08 \\
\hline T5 & Muslin Cloth Bag & 53.68 & 43.01 & 47.72 & 54.61 & 41.50 & 2.705 & 25.51 \\
\hline T6 & Jute Bag & 55.18 & 45.24 & 51.86 & 64.47 & 36.50 & 2.752 & 25.17 \\
\hline $\mathrm{T} 7$ & Control & 57.57 & 40.30 & 45.65 & 51.34 & 29.50 & 2.250 & 24.29 \\
\hline $\mathrm{SE}(\mathrm{m})$ & & 1.63 & 0.74 & 1.03 & 1.80 & 3.21 & 0.038 & 0.48 \\
\hline
\end{tabular}




\begin{tabular}{|c|c|c|c|c|c|c|c|c|}
\hline $\mathrm{CD}_{0.05}$ & & 4.26 & 2.01 & 3.32 & 4.68 & 8.90 & 0.110 & 1.32 \\
\hline $\mathrm{CV}$ & & 17.63 & 10.94 & 12.63 & 14.15 & 27.72 & 9.54 & 11.57 \\
\hline
\end{tabular}

Table 2: Effect of fruit bagging on fruit physical parameters and yield of tomato cv. Lakshmi

\begin{tabular}{|c|c|c|c|c|c|c|c|c|}
\hline Treatments & Treatment details & $\begin{array}{c}\text { TSS } \\
\left({ }^{0} \text { Brix }\right)\end{array}$ & $\begin{array}{c}\text { Total } \\
\text { sugar } \\
(\%)\end{array}$ & $\begin{array}{l}\text { Reducing } \\
\text { Sugar }(\%)\end{array}$ & $\begin{array}{c}\text { Titrable } \\
\text { acidity } \\
(\%)\end{array}$ & $\begin{array}{c}\text { Ascorbic } \\
\text { acid } \\
\left(\mathrm{mg100}^{-1} \mathrm{~g}\right)\end{array}$ & 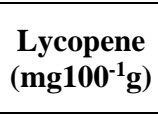 & $\begin{array}{c}\text { Dry wt. } \\
(\%)\end{array}$ \\
\hline $\mathrm{T} 1$ & News Paper Bag & 6.18 & 1.90 & 1.81 & 0.47 & 26.17 & $293.73 \mathrm{a}$ & 5.25 \\
\hline $\mathrm{T} 2$ & Butter Paper Bag & 5.89 & 1.50 & 1.90 & 0.45 & 27.33 & 310.26 & 5.43 \\
\hline T3 & Transparent Polythene Bag & 4.94 & 1.20 & 1.34 & 0.48 & 21.09 & 258.54 & 4.58 \\
\hline $\mathrm{T} 4$ & Black Polythene Bag & 4.01 & 1.42 & 1.27 & 0.49 & 20.84 & 152.33 & 4.40 \\
\hline T5 & Muslin Cloth Bag & 5.37 & 1.27 & 1.55 & 0.48 & 22.88 & 265.90 & 4.21 \\
\hline T6 & Jute Bag & 5.92 & 1.00 & 1.60 & 0.47 & 23.51 & $276.22 \mathrm{~b}$ & 4.55 \\
\hline $\mathrm{T} 7$ & Control & 4.12 & 1.46 & 1.08 & 0.50 & 19.36 & 231.64 & 4.70 \\
\hline $\mathrm{SE}(\mathrm{m})$ & & 0.29 & 0.07 & 0.07 & 0.01 & 0.37 & 4.80 & 0.09 \\
\hline $\mathrm{CD}_{0.05}$ & & 0.76 & 0.21 & 0.21 & NS & 1.02 & 14.34 & 0.27 \\
\hline $\mathrm{CV}$ & & 15.29 & 10.23 & 10.23 & 13.56 & 14.52 & 16.29 & 12.13 \\
\hline
\end{tabular}

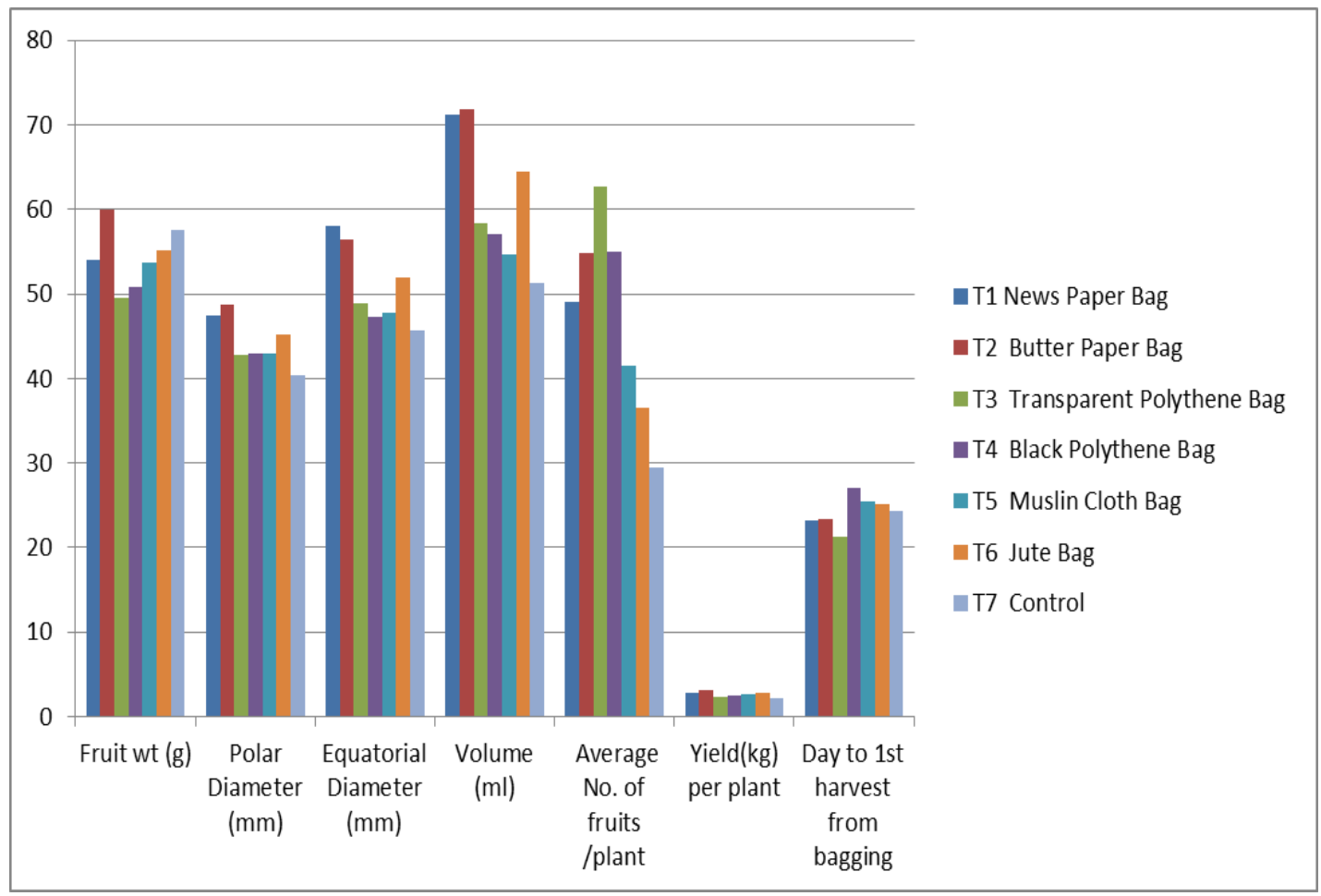

Fig 1: Effect of fruit bagging on different fruit physical parameters of tomato.

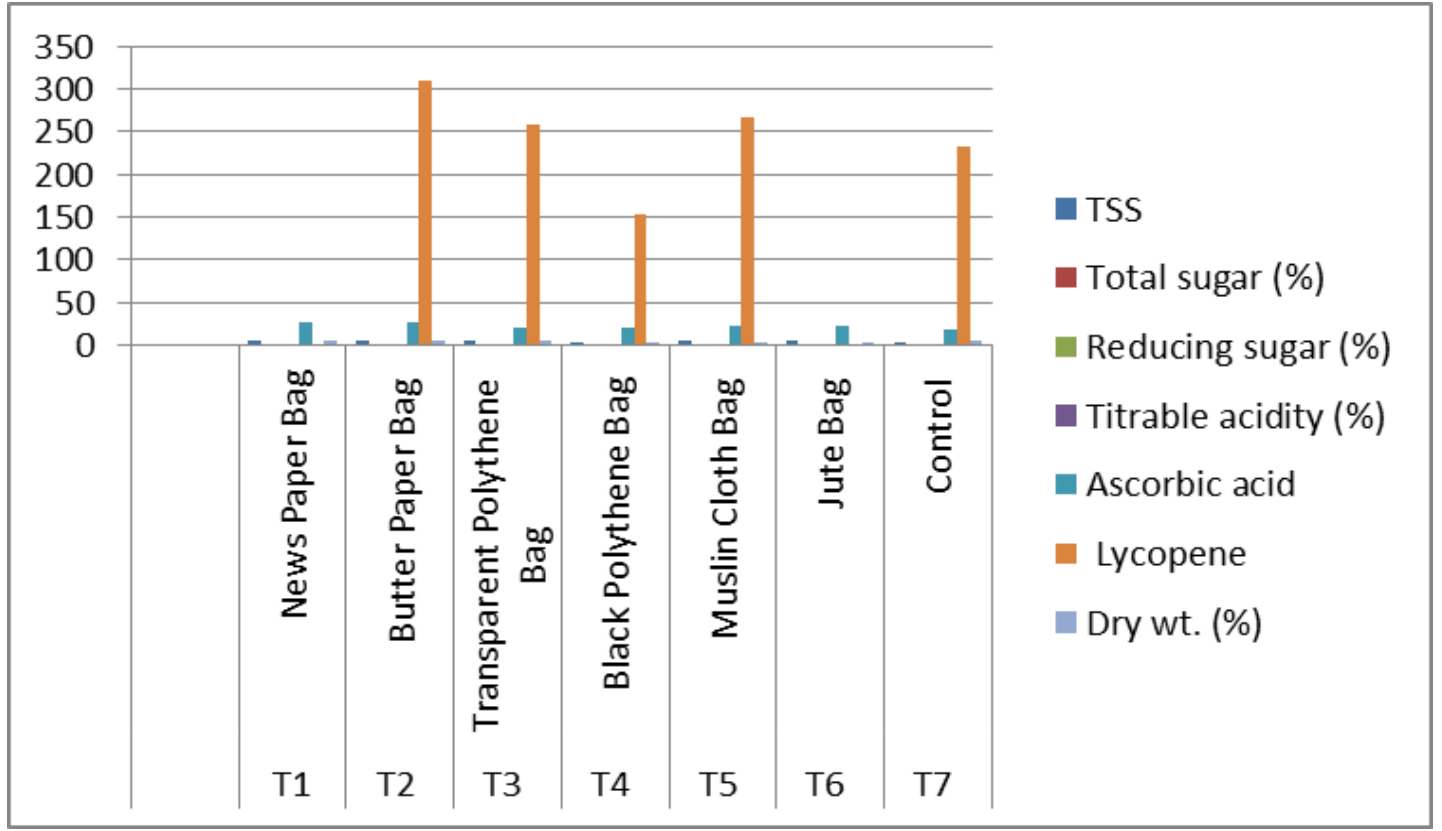

Fig 2: Effect of fruit bagging on average number of fruits, yield per plant and days to first harvest 


\section{References}

1. Knapp S, Peralta IE. The Tomato (Solanum lycopersicum L., Solanaceae) and Its Botanical Relatives. Springer, Berlin, Heidelberg, 2016, 7-21.

2. Ploeg DV, Heuvelink E. Influence of sub-optimal temperature on tomato growth and yield: a review. The Journal of Horticultural Science and Biotechnology 2005;80(6):652-659.

3. Daniela Erba, M. Cristina Casiraghi, Albert Ribas, Rafaela Cáceres, Oriol Marfà, et al. Nutritional value of tomatoes (Solanum lycopersicum L.) grown in greenhouse by different agronomic techniques. Journal of Food Composition and Analysis Elsevier 2013;31(2):45251.

4. Md. Tariqul Islam, Md. Shazadur Rahman, Mst. Moli Akter, Md. Nazmul Hasan and Md. Sorof Uddin. Influence of Pre-Harvest Bagging on Fruit Quality of Mango (Mangifera indica L.) cv. Langra. Asian Journal of Agricultural and Horticultural Research 2019;4(4):110 .

5. Angelika Krumbein, Dietmar Schwarz, Hans-Peter Kläring. Effects of environmental factors on carotenoid content in tomato (Lycopersicon esculentum (L.) Mill.) grown in a greenhouse. Journal of Applied Botany and Food Quality 2006;80:160-164.

6. Vida Opoku Edusei, Eric William Cornelius. Effect of Film Packaging on the Quality of Tomato Fruits under Ambient Conditions. Journal of Tropical Crop Science 2015;2(3):1-5.

7. SK. Purbey, Amrendra Kumar.Effect of pre-harvest bagging on quality and yield of litchi (Litchi chinensis sonn.) fruits. An International Quarterly Journal of Environmental Science 2015;VII: 197-201.

8. PM. Haldankar et al. Studies on Influence of Bagging of Fruits at Marble Stage on Quality of Mango cv. Alphonso. Journal of Plant Studies 2015; 4(2):1-9.

9. Debnath S, Mitra SK. Panicle bagging for maturity regulation quality improvement and fruit borer management in litchi (Litchi chinenesis). Acta Horticulturae 2008;773:201-209.

10. GLD. Leite et al., Bagging tomato fruits: A viable and economical method of preventing diseases and insect damage in organic production. Florida Entomological Society 2014;97(1):50-60.

11. Van Der Ploeg A, Heuvelink E.. Influence of sub-optimal temperature on tomato growth and yield: a Review. Journal of Horticultural Science \& Biotechnology 2005;80(6):652-659.

12. Hofman PJ, Smith LG, Joyce DC, Johnson GL, Meiburg GF. Bagging of mango (Mangifera indica cv. "Keitt") fruit influences fruit quality and mineral composition. Postharvest Biology and Technology 1997;12:83-91.

13. Joyce DC, Beasley DR, Shorter AJ. Effect of pre-harvest bagging on fruit calcium levels, and storage and ripening characteristics of "Sensation" mangoes. Australian Journal of Experimental Agriculture 1997; 37:383-389.

14. Worrell DB, Carrington CMS, Huber DJ. Growth, maturation and ripening of breadfruit, Artocarpus altilis (Park.) Fosb. Scientia Horticulturae 1998;76:17-28.

15. D.T. Santosh*, K.N. Tiwari and Raja Gopala Reddy. Banana Bunch Covers for Quality Banana Production A Review. International Journal of Current Microbiology and Applied Sciences 2017;6(7):1275-1291.

16. Kireeti A, Haldankar PM, Parulekar YR. Studies on effect of types of bag at egg stage on mango fruit (cv.
ALPHONSO) The Asian Journal of Horticulture 2016; 11(1):58-62.

17. Agarwal S, Rao AV. Tomato lycopene and its role in human health and chronic diseases. CMAJ 2000;163(6):739-44.

18. Amarante C, Banks NH, Max S. Effects of preharvest bagging on fruit quality and postharvest physiology of pears (Prunus communis). New Zealand Journal of crop and Horticultural Science 2002a;30:99-107.

19. Amarante C, Banks NH, Max S. Preharvest bagging improves packout and fruit quality of pears (Pyrus communis). New Zealand Journal of crop and Horticultural Science 2002b;30:93-98.

20. Ann PJ, Lu LS, Chuang TY, Kao CW. Effect of fruit bagging and mulching on control of mango fruit anthracnose disease. Plant Pathology Bulletin 1998;7:1926.

21. AOAC. (Association of Official Analytical Chemists). Official Methods of Analysis., Washington. D.C, 1996.

22. Awad MA, Al-Qurashi AD. Gibberellic acid spray and bunch bagging increase bunch weight and improve fruit quality of 'Barhee' date palm cultivar under hot arid conditions. Scientia Hort 2012; 138:96-100.

23. Chonhenchob V. Preharvest bagging with wavelength selective materials enhances development and quality of mango (Mangifera indica L.) cv. NAM DOK MAI. J. Sci. Food \& Agric 2011; 91(4):664-671.

24. Chunhui Huang, Bo Yua, Yuanwen Teng, Jun Su, Qun Shu, Zaiquan Cheng et al. Effects of fruit bagging on coloring and related physiology, and qualities of red Chinese sand pears during fruit maturation, Scientia Horticulturae 2009;121:149-158.

25. Fallahi E, Colt WM, Baird CR, Fallahi B, Chun IJ. Influence of nitrogen and bagging on fruit quality and mineral concentrations of 'BC-2 Fuji' Apple. Hort. Technol 2001;11(3):462-465.

26. Kassem HA, Omar AKH, Ahmed MA. Response of zaghloul date palm productivity, ripening and quality to different polyethylene bagging treatments. AmericanEurasian J. Agric. \& Environ. Sci 2011;11(5):616-621,

27. http://eagri.tnau.ac.in/eagri50/HORT381/lec05.html

28. Nagaharshitha D, Khopkar RR, Haldankar PM, Haldavanekar PC, Parulekar YR. Effect of Bagging on Chemical Properties of Mango (Mangifera indica L.) cv. Alphonso. Agrotechnology 2014;3:1-4.

29. NBH Database 2015, 177-178.

30. Purbey SK, Kumar A. Effect of pre-harvest bagging on quality and yield of litchi (Litchi chinensis Sonn.) fruits. The Ecoscan 2015;VII:197-201.

31. Rana MK. Olericulture in India. Kalyani Publishers, New Delhi, 2008, 43-48.

32. Datta S. Impact of climate change in Indian horticulture. International journal of science, environment and technology 2013;2(4):661-671.

33. Thamburaj $\mathrm{S}$ et al. Text book of vegetables, tuber crops and spices. ICAR, 2001, 10-11.

34. Sandra Knapp et al., The tomato (Solanum lycopersicum L. solanaceae) and its botanical relatives. 5505 Chacras de Coria, Argentina 2013; 2:7-11.

35. Sharma RR, Reddy SVR, Jhalegar MJ. Preharvest fruit bagging a useful approach for plant protection and improved post-harvest fruit quality - a review. J Hort Sci. \& Biotechnology 2014;89(2):101-113. 
36. Vanitha SM, Chaurasia SNS, Singh PM, Prakash S, Naik. Vegetable Statistics. Technical Bulletin No. 51, IIVR, Varanasi, 2013, 250.

37. Xu XU, Chen HB, Huang RY, He YJ. Effects of bagging on fruit growth and quality of carambola. Acta Hort 2008;773:195-200.

38. Yang WH, Zhu XC, Bu JH, Hu GB, Wan HC, Huang $\mathrm{XM}$. Effects of bagging on fruit development and quality in cross-winter off-season longan. Scientia Hort 2009; 120:194-200.

39. https://sg.inflibnet.ac.in/jspui/bitstream/10603/4071/11/1 1_chapter2.pdf

40. H. Supriya Devi1, K. Mamocha Singh. Effect of Intercropping on the Infestation of Helicoperva armigera. Indian Journal of Hill Farming 2019;32(1):57-59.

41. R. R. Sharma et al., Pre-harvest fruit bagging influences fruit color and quality of apple cv. Delicious. Agricultural Sciences 2013;4(9):443-448.

42. Fan, X. and Mattheis, JP. Bagging "Fuji" apples during fruit development affects color development and storage quality. Hort Science 1998; 33, 1235-1238.

43. P. M. Haldankar et al., Studies on Influence of Bagging of Fruits at Marble Stage on Quality of Mango cv. Alphonso. Journal of Plant Studies 2015;4(2):12-20.

44. Fallahi $\mathrm{E}$ et al., Influence of nitrogen and bagging on fruit quality and mineral concentrations of 'BC-2 Fuji' Apple. Hort Technology 2001; 11(3):462-465.

45. Harach $\mathrm{S}$, Wanichkul K. Influences of bagging methods on fruit quality of guava (Psidium guajava L.) cv. Yen Song. Kamphaengsaen Acad. J 2006;4:41-47. 